\title{
Legal R/realism and Jurisprudence: Ten Theses
}

\author{
William Twining*
}

\section{INTRODUCTION}

At Oxford, Salmond on Torts had been my favorite textbook (Salmond 1953). It was a conventional, lucid, expository work. Shortly after I had graduated in 1955, a solicitor specializing in personal injuries told me to forget what I had learned in the books because nearly all of his cases were settled out of court with an insurance company or the Motor Insurers' Bureau involved. Anyway, he said, the system needed drastic reform. I suffered culture shock. So I began to wonder: how could one understand the law relating to personal injuries if one knows nothing about insurance, settlement, the damages lottery, and alternatives to the common law action for negligence? ${ }^{1}$ I felt misled, let down, even betrayed by Salmond and my teachers. This is a common complaint by students in most modern legal systems. Of course, I was naïve, for no one in Oxford had claimed that what they were offering was in any way realistic. Brian Leiter cites a colleague as saying: "Anyone teaching constitutional law who discusses only the doctrine is guilty of educational malpractice" (Leiter 2003, citing Powe 2001). That was how I felt about Torts. But the context in England was different. When I complained, I was met with standard, complacent answers:

* More detailed exploration of nearly all of the ideas presented here can be found in the following works: William Twining, The Great Juristic Bazaar (2002) (hereafter GJB) esp. chapters 4, 5, and 6; Globalisation and Legal Theory (2000-2001) (hereafter GLT) especially chapters 2, 5-8; General Jurisprudence (2009) (hereafter GJP) esp. chapters 1, 6-7, 8, 10, and 11; Rethinking Evidence, $2^{\text {nd }}$ edition, (2006) (hereafter RE); Globalisation and Legal Scholarship (2011) (hereafter GLS); and Karl Llewellyn and the Realist Movement, $2^{\text {nd }}$ edition (with Afterword, 2012) (hereafter, KLRM, and Afterword.).

I am grateful for helpful comments by the editors, David Restrepo Amariles, Hanoch Dagan, Maksymilian Del Mar, Sioneaidh Douglas-Scott, Brian Tamanaha, and especially Andrew Halpin.

This is an attempt to restate and update a position on what is involved in being "realistic" about law. These theses are advanced in a deliberately condensed form. The endnotes provide signposts in various directions. As noted, for more details, I refer the reader to the works referred to in the paragraph above.

1 Atiyah's Accidents, Compensation and the Law (1970) can be held out as a "realistic" counterpoint to Salmond on Torts. See also Atiyah (1997). There is room for genuine disagreement about whether Atiyah's work undermines, rivals, or merely complements works like Salmond. By the $16^{\text {th }}$ edition (1973), the editor of Salmond had added a seven-page section on "The Influence of Insurance." 
"We do not claim that we are preparing you for practice."

"You will learn about such matters when you study procedure." (This was untrue; the bar exams were just as doctrinal.)

"Be realistic, you need to mug up Salmond to pass both degree and professional examinations."

"Such pedestrian matters are just common sense."

And, more convincingly:

"Studying the law in action presupposes that you have a clear idea about what is in action. So your practitioner friend was wrong, you need to study the books before getting involved in the action."

The purpose of this paper is to restate some basic points about Legal R/realism as an aspect of Jurisprudence. ${ }^{2}$ Most of the general theses should be familiar and, I hope, acceptable to most sociolegal scholars, but a few points may appear to be provocative.

Classical American Legal Realism (ALR) reacted against an ill-defined "formalism" in academic law in the period before World War II. The New Legal Realism (NLR), still in reaction to the dominance of doctrinal approaches, has developed in a quite different intellectual and ideological context in an era in which new technology, bureaucratic audit, evidence-based practice, evidencebased policy, and "globalization" are among matters in the foreground of academic concerns. ALR has been treated as an American school or movement in Jurisprudence, even though its main concerns were with quite particularistic matters to do with legal education and scholarship and law reform. The New Legal Realism (NLR), open-ended and diverse, has also been mainly concerned with teaching and research in the American law schools, and only peripherally with its relationship to legal theory.

My standpoint is that of a British - maybe mid-Atlantic - jurist of realist persuasion concerned about the health of our discipline as a collective transnational enterprise and of jurisprudence as its theoretical part in a period of immense challenges and rapid change. This paper argues that if "realism" is to flourish it needs to advance one strong, but limited, theoretical claim that challenges doctrine-centered legal theory: namely, that empirical dimensions of law and justice ${ }^{3}$ are a necessary part of the enterprise of

2 This paper focuses on jurisprudence, as the theoretical part of our discipline, as carried out mainly by law teachers and judges associated with British and U.S. law schools, such as Hart, Fuller, Dworkin, Raz, Finnis, MacCormick, and Posner. For reasons of space, it does not deal directly with social theory and theoretical dimensions of the sociology of law, but much of the argument applies to them. Of course, there are no clear boundaries between jurisprudence and social theory, and some individuals, such as Roger Cotterrell and Philip Selznick, have contributed to both.

3 The term echoes Julius Stone, who also insisted on the interdependence of analytical, empirical, and normative concerns (Stone 1956). See generally GJB, ch.8. Anyone who agrees that understanding law requires knowledge of what law is like in "the real world" is an empiricist in the broad sense used here. "Empirical" here includes, but is broader than, the social sciences, as it extends to practical experience, legal history, and scholarly work such as Brian Simpson's contextual studies of leading cases (Kritsiotis 
understanding law. ${ }^{4}$ Any theory of law or jurisprudential perspective that denies this proposition, implicitly or explicitly, is damaging to the health of the discipline of law, as it is practiced in the West and more widely, not just in the United States. ${ }^{5}$ Most of what I shall call doctrinal legal theory rejects or ignores that claim. ${ }^{6}$

\section{TEN THESES}

\section{A. The Discipline of Law and the Functions of Jurisprudence}

1. The primary mission of a scholarly discipline should be advancing and disseminating theoretical and practical knowledge and understanding about the subject-matters of that discipline. ${ }^{7}$ The primary mission of the discipline of law should be the advancement and dissemination of theoretical and practical knowledge (know-what, know-why, know-how) and understanding about the subject-matters of that discipline.

2. Jurisprudence, broadly interpreted, is the theoretical part of the discipline of law. A theoretical question is one posed at a relatively high level of abstraction.

and McCrudden 2012; Simpson 1984, 1995.) "Empiricism" is a contested concept in philosophy: "There are almost as many empiricisms as there are empiricists, but what these views or approaches have in common is an emphasis on the importance of experience in the formation of concepts and to the acquisition of knowledge. The foil to empiricism is rationalism, which emphasizes instead the importance of thought and knowledge of material that is in some sense independent of experience" (Lipton, 2001) (a useful brief history of the philosophical debates). Of course, in law, and especially in respect of legal education and training, much knowledge and understanding of the law in action, especially lawyers' action, is obtained by experience and observation in the workplace. On the views of English legal practitioners on what is best learned in the classroom and what in the workplace, see "Legal Education and Training Review Report" (2013) http://letr.org.uk/the-report.

4 The term "understanding law" is sometimes used to refer to understanding the concept or nature or even "essence" of law. Here it is used, as in introductory books and courses with that title, to refer to all of the subject-matters of the discipline as it is institutionalized at a given time or place.

5 The activity of legal theorizing, as used here, includes, but is much wider than, enquiries into the nature or essence of law, or analysis of conceptions of law. It includes any general enquiries directed to understanding legal phenomena, both law as ideas and law as social facts.

6 Why would any serious legal scholar or theorist disclaim any concern with being realistic about law? Brian Leiter states that he finds it hard to fathom that anyone disputes the truth of legal realism. I sympathize with Leiter's thesis about (moderate) naturalism (Leiter 2007) and with his colleague Powe's sentiment (see quote p.121) but neither of these are part of my argument here (see notes 23 and 46 below). The answer to that puzzle is outside the scope of this paper. The fact is that most mainstream legal philosophers and jurists appear to dispute the truth of legal realism as interpreted here - the main examples cited in the text are Hart, Dworkin, Raz. Of course, some leading jurists, such as Dworkin, may have misguidedly thought that they were being "realistic."

7 The Full Complement of Riches (British Academy 2004). "Riches" and "wealth" are explicitly interpreted very broadly as extending beyond economic wealth (see GJP, Preface). This chapter is written in much the same spirit as Martha Nussbaum's Not for Profit (2010) and recent efforts to make the case for the value to society of the social sciences and the humanities (cf. American Academy of Arts and Sciences $(2013))$. 
Besides legal philosophy (the most abstract part), it encompasses many interrelated questions at varying levels of abstraction. ${ }^{8}$

The activity of theorizing about law has many overlapping functions. ${ }^{9}$ In the present context, one important function is to critically evaluate and guide the practices and theory of legal scholarship and legal education - that is, to monitor the health of the discipline as a whole and its constituent and shifting subdisciplines. ${ }^{10}$ This role is of central relevance here because an important connecting thread between different historical forms of $\mathrm{R} /$ realism has been a reaction against tendencies to focus narrowly or even exclusively on doctrine in respect of scholarship, legal education, and legal theory and to criticize these tendencies as being "unrealistic."

3. A distinction between law as ideas and law as social facts is significant in the present context.

This distinction identifies two important historical strands in Western traditions of academic law regarding the practices of legal scholarship and legal theory. They have often been perceived and presented as rival or warring perspectives and approaches. One of the main concerns of a realist perspective, as interpreted here, is to challenge this distinction on the ground that understanding law needs to combine conceptual, doctrinal, normative, and empirical perspectives in different ways at different levels (GJP $30-31,118-121) .{ }^{12}$

8 An example of different levels of enquiry, relevant in the present context, is: dispute processing in general; dispute processing in state law, in litigation; dispute settlement by court; adjudication in general; adjudication on questions of law, on questions of law in hard cases, in common law systems, in the United States, in American state appellate courts, in a particular court at a particular time, in a single opinion in one case; and so on, up and down several ladders of abstraction (GJP, 21-22, 258). For a further example, on reasoning, see note 51 below.

9 These include critical intellectual history; synthesis; conceptual analysis; construction of normative theories and standards; constructing, refining, and testing empirical hypotheses about legal phenomena; developing working theories for participants; and the critical identification, analysis, and assessment of important presuppositions and assumptions underlying legal discourse generally and particular phases of it (GJP, ch.1-8, esp. 1.3). All of these can be relevant to monitoring the health of our discipline.

10 For example, in recent years there have been significant movements to "rethink" some subdisciplines, including international law, comparative law, and empirical legal studies. One role of legal theory is to assist critically in such internal critiques (GLS, 35-38). A recent inspection of the library catalogue of the University of Miami Law School revealed nearly 100 relatively recent books with "Rethinking" in the title. My Rethinking Evidence can be interpreted as a case-study of what is involved in rethinking a sub-discipline in a broader fashion from a realist or contextual perspective (RE, $366-368$ ).

"11 On some different targets of charges of "unrealism," see Schauer (2012, xv-xvii).

12 In discussing the work of Neil MacCormick (2007) in relation to the concept of a legal system, Julie Dickson uses a similar distinction and agrees with MacCormick that we need both and that they are closely inter-related (Dickson 2012, 145-159). In this chapter, following MacCormick, the term "legal phenomena" encompasses both law as ideas (doctrine) and law as social facts. Both are institutional facts. 
Familiar contrasts between the law in books and the law in action ${ }^{13}$ and between law as rules and law as institutions, processes, and practices echo the distinction between law as ideas and law as social facts rather imprecisely. One version that is particularly interesting is Ronald Dworkin's distinction between the doctrinal concept of law and the sociological concept of law. ${ }^{14}$ In a rash statement in a polemical article, he went so far as to say: "The sociological question has neither much practical nor much philosophical interest. The doctrinal question, on the contrary, is a question both of enormous practical and considerable philosophical interest" (Dworkin 2006a, 97).

Later Dworkin modified his position by restricting his denial of "philosophical interest" to abstract conceptual enquiries into the "essential" nature of law (Dworkin 2006b, 4 , cf. formulations at 3, 227-228). ${ }^{15}$ He grudgingly acknowledges the existence of legal sociology and legal anthropology, but still treats such empirical legal studies $^{16}$ as being of not much practical interest and as marginal and subordinate to the ideas of jurisprudence and law as moral enterprises (Dworkin 2006b, 3-5) ${ }^{17}$

13 On different meanings of "law in action" see note 32 below. On "the gap problem," see GJP (318-320) and Nelken (1981).

${ }^{14}$ He also expresses this in terms of "the doctrinal question" and "the sociological question" (as if there is only one central question in legal philosophy, let alone jurisprudence) (Dworkin 2006b, 4-5, 227-232). Dworkin's last major work was entitled Justice for Hedgehogs (2011). It sets out powerfully his mature theory of private and public morality. I consider it a major contribution to ethics, but less persuasive in respect of jurisprudence just because it downplays and ignores the empirical dimensions of understanding law. It is strong on aspiration, but weak on reality. In my view this is unfortunate and unnecessary. The moral dimensions are an important aspect of understanding legal phenomena, but the discipline of law is not solely or mainly a moral enterprise in Dworkin's sense. On the hedgehog/fox metaphor, see note 34 below.

15 See further GJP (25-30), Schauer (2009) and Halpin (2006, 67). Justice in Robes (Dworkin 2006b, ch. 6) is a powerful attack on the kind of analytical legal philosophy that claims to be "an independent, selfcontained subject and profession."

16 In this context the term "empirical legal studies" is used broadly to cover both quantitative and qualitative studies, but also information based on experience, such as evidence given by experienced experts and practitioners and what Karl Llewellyn called "horse sense." See further GJP (ch. 8).

${ }^{17}$ It is difficult to believe that Dworkin really intended to suggest that there are no interesting philosophical questions underpinning empirical legal studies or other nondoctrinal studies of the kind listed in notes 1-3 above. A charitable interpretation is that other philosophical issues were not directly interesting to him personally or relevant to his (narrow) question about the relationship between legal and moral propositions (see above note 14). John Gardner (2012, 296-297 n) criticizes me for veering "dangerously close to a Dworkinian diktat about what is interesting." Of course, Gardner as an individual is free to follow his own intellectual interests, but this does not address concerns about the health of the discipline of law and of legal theory as a collective enterprise and about the role of theory in monitoring that health, especially where communication between different kinds of inquiry could be substantially improved. On this point, see Nicola Lacey's Jurisprudence Lecture, "Institutionalising Responsibility" (Lacey 2013) (showing how concepts like responsibility and legality have to be understood in their historical and institutional contexts). In his writings on constitutional and policy issues concerning subjects such as abortion, euthanasia, and medicare (e.g., Dworkin 1994 and his many brilliant essays in the New York Review of Books), Dworkin treats empirical data as sometimes relevant, but not to basic principles of morality (e.g., 2011, 418-419). On Dworkin as a possible rule-skeptic, see below note 56 . 
Dworkin's original statement and his partial retraction are revealing for both positive and negative reasons:

First, Dworkin's conception of "doctrine" usefully includes principles, concepts, and distinctions in addition to rules. This sets up a more robust version of the tradition against which realism has reacted than "law is rules" conceptions and labels such as formalism, legal dogmatics, blackletter law, the expository orthodoxy, and law in books. It allows for forms of exposition that are rigorous and sophisticated. ${ }^{18}$ The basic realist objection is against the dominance of or an exclusive emphasis on doctrinal studies, not on doctrinal studies as such.

Second, this distinction is useful as a label indicating two distinctive traditions within Western academic law, in which the doctrinal tradition has been paramount throughout most of history both in respect of legal scholarship and legal theory. Competing concepts or traditions of legal positivism and natural law are treated as falling within the doctrinal concept. Most canonical jurists in the Western tradition are doctrinal theorists, mainly focused on municipal (state) law. ${ }^{19}$

Dworkin provides a useful reference point because he stakes out a clear position that is both revealing and open to attack on several other fronts:

First, Dworkin treats the distinction between doctrine and "sociology" as crucial, because they are different forms of enquiry that are conceptually separate. One of the main concerns of a realist perspective, as interpreted here, is to challenge this distinction on the ground that understanding law and legal phenomena combines conceptual, doctrinal, normative, and empirical perspectives in different ways at different levels and in different contexts. In this context "doctrine" and "empirical legal studies" are at best very rough labels for broad fields with no clear boundaries.

Second, Dworkin's use of "sociological" (i) is very loose if it is intended to refer to the social sciences generally; ${ }^{20}$ (ii) is narrow if it implies that the only (significant) enquiries in law that are not doctrinal are "sociological"; ${ }^{21}$ (iii) seemingly restricts legal philosophy to a single main question about the doctrinal concept of law:

18 Compare Andrew Halpin's "richer notion" of legal doctrine, including not only rule-formulations, but also principles, differentiated conceptions of interpretive roles, and informed conceptions of the nature of legal materials, all of which are normally "beneath the surface" (Halpin 2004, ch. 1).

19 Some leading members of the critical studies movement focused emphatically on legal doctrine, but it would be misleading to categorize them as "doctrinal theorists."

${ }^{20}$ It is also crudely emotive: in Oxford "sociological" has often been used as a term of disparagement.

21 This broad interpretation of Dworkin's conception of "sociology of law" seemingly excludes nondoctrinal studies that are not social scientific. For example, on the academic side, study of inferential reasoning from evidence about questions of fact and other reasonings in legal contexts; probabilities and proof; historical and historiographical enquiries (other than those that are purely doctrinal); the study of legal traditions (mainly law as ideas); standpoint analysis; narrative analysis; artificial intelligence; computer applications; theoretical questions about describing, comparing, and generalizing about legal phenomena - both micro- and macro-comparative legal studies; the implications for law of neuroscience and artificial intelligence, and so on. It is a strange view of our discipline if all of these enquiries fall outside it. It also seemingly excludes what is learned by practical experience or close observation of actual practices. On the views of practitioners about what is best learned in the workplace rather than the classroom (and semble by fieldwork), see the important English Legal 
namely, "whether and when morality figures in the truth conditions of law" (Dworkin 2006b, 4-5). In the same paragraph he uses a slightly different formulation, which makes clear that it is confined to doctrine: "The main question is whether and how morality is relevant to deciding which propositions of law are true, not how we label whatever moral principles we do take to be relevant" (Dworkin 2006b, 5). This is a much narrower conception of legal philosophy, let alone jurisprudence, than is adopted here.

Third, Dworkin's formulations are an interesting example of the gravitational pull of doctrinal studies for legal theorists. The great majority of Western jurists have focused on questions about the identification, nature, normativity, legitimacy, justice, and injustice of law considered as legal doctrine. Similarly, common law jurists have been lured to focus on decisions and reasoning about questions of law in appellate courts as somehow central to understanding legal phenomena. ${ }^{22}$ Some American Realists are regularly perceived to have succumbed to this strong gravitational pull. ${ }^{23}$

Education and Training Review Report (England and Wales) (2013, esp. ch. 2). Experience of legal practice at first or second hand is one of the most important sources of realistic understanding of the law in action. Of course, it is important to bear in mind that lawyers' action is only one aspect law in action generally. On "law in action" as a concept, see below note 32.

22 The obsession with the upper-level courts and in particular the U.S. Supreme Court is one aspect of American exceptionalism. For most non-American jurists, legislation, regulation, enforcement, impact, and attitudes to law etc. are as important an aspect of understanding law as higher-level adjudication. On overconcentration on contested trials, contested jury trials, and appellate courts, and the significance of a total process model of litigation, see RE, 169, 220-221, 249-252, and 314. I have some sympathy with the idea that the point of application is a crucial point in the interpretation of doctrine, so that particular decisions are in some sense "central" (Twining and Miers 2010, 131-132, 145147), but that is different from exaggerating the importance of judges and appellate cases in most legal systems.

${ }^{23}$ For example, Brian Leiter treats the proposition that "judges respond primarily to the stimulus of facts" as the Core Thesis of classical ALR (Leiter 2007, 21, cf. 23-4). This proposition is confined to decisions on questions of law by American, mainly appellate, judges at a particular period. If a contemporary realist were to take Leiter's Core Thesis seriously other than as a partial historical claim about ALR, she would have to rephrase it as a hypothesis to be tested, or as an open question (e.g., what factors have influenced common law/American/federal judges [when] on questions of law?") because the Core Thesis is an empirical generalization or hypothesis about (American?) (appellate?) judges at some unspecified times in the past. I find Leiter's naturalist reconstruction of ALR to be interesting, though unduly narrow (for a brief discussion, see Afterword 440-441; see further Halpin 2009, 147-153).

Leiter, in concentrating on adjudication on questions of law, states that ALR interest in empirical legal studies was "unrepresentative" (citing The Cheyenne Way and Moore's studies). This excludes Frank (1949) on fact-finding; it also overlooks Llewellyn on rules (2011), as well as his idea of "horse sense" (expertise based on experience), and his much-criticized "barefoot empiricism" in respect of divorce, commercial practice, and law reform. More importantly, this ignores empirical research at Johns Hopkins and Yale notably by Cook, Yntema, Oliphant, Douglas, Moore, and Callaghan, and Clark and Corstvet, at least some of whom are included in nearly all lists of "Realists" (Schlegel 1995). See also critiques of the Restatement project (a good survey of the criticisms is Merryman 1954). This is not the place to go into further detail about interpretations of ALR (but see GJB, ch. 5 and 6 and Afterword). 
Fourth, Dworkin's bizarre and unnecessary dismissal of the practical value and theoretical interest of empirical legal studies hardly deserves a response. ${ }^{24}$ But it illustrates the chasm between sociolegal theorizing (however identified) and the views of those contemporary jurists and legal scholars who are still under the gravitational pull of "the doctrinal concept." (On Raz's more sympathetic treatment of empirical legal studies and legal history see below (pages 139-140).

\section{B. R/realism}

4. Concern to be "realistic" about the law in action has never been an American exclusive. It is important to distinguish clearly between American Legal Realism (ALR) as an historical phenomenon and more widespread concerns about being "realistic" about law.

As Brian Tamanaha reminds us (2013), there is a long tradition in the West at both theoretical and practical levels which shares such concerns. ${ }^{25}$ Hence we need a distinction between "Legal Realism" as a name for a particular movement among American academic lawyers at a particular time and "legal realism" as a much more general approach and focus of concern (GJB, 102-105).

5. Discussion of legal realism in respect of contemporary issues needs to break free from historical debates about interpretations of ALR and its significance. ${ }^{26}$

Macaulay, Mertz, and others have argued that, while the history of ALR is interesting, dwelling on the past is likely to have a constraining effect on the New Legal

24 On the question: Was Dworkin's denial serious? See above notes 17 and 21.

25 Tamanaha (2013) argues that what he calls "the third pillar" of jurisprudence has found theoretical expression in various ways through Montesquieu, Ehrlich, the Historical School, and Ihering, as well as through Pound and American Legal Realism. Such lists can be idiosyncratic: my list would also include Machiavelli, Santi Romano, Hume, Adam Smith, and Julius Stone, who was influenced by Pound. Like Tamanaha, Hanoch Dagan argues for a distinctive realist synthesizing theory of law reconstructed from charitable interpretations of some classic texts (Dagan 2013a and 2013b). Dagan's theory of law is very interesting, but my argument is that any general theory of law should accommodate "realistic perspectives," as interpreted here, and that jurists of many different persuasions should accept the thesis that general legal theories or approaches that deny this proposition are seriously defective. On Dagan, see further below note 41.

${ }^{26}$ I make one exception here. I have not moved far enough out of the shadow of Karl Llewellyn to disclaim his influence. For example, several of his precepts underpin my argument: "Technique without ideals is a menace; ideals without techniques are a mess" (Llewellyn 1952, 23); "Knowledge ... does not have to be scientific, in order to be useful and important" (discussed in KLRM, 190-193); "Doctrine brittle and neat is the tool of tender minds in pursuit of policy that can be embraced without using one's intellect" (KNL, lecture in "Law in our Society," 1958); "[Realism] applies to anything" (Llewellyn 1960, 509-510); "If Jurisprudence of necessity includes a study of ideals in law, then realism is not [co-extensive with] jurisprudence. If, as I think, jurisprudence contains [seven] sub-disciplines, then realism deals with two of them: craft techniques and descriptive sociology" (Llewellyn 1942-1943, 5, cited KLRM, 575). I agree with the spirit, but not necessarily the exact formulations, of all of these dicta. 
Realism (NLR) (Mertz 2016). There may be some actual continuities and some unfinished agenda, ${ }^{27}$ as well as some false claims to ancestry (de Been 2008). However, there are several good reasons for contemporary jurists to distance themselves from these earlier debates: (a) the intellectual climate has changed and developed; (b) most classic legal realist texts have been superseded; ${ }^{28}$ (c) the local history of ALR is not directly relevant to developing realistic approaches across national boundaries ${ }^{29}$ - "realist" approaches in other countries and traditions have different histories; (d) a misleading mythology has grown up around ALR (I have argued elsewhere that most generalizations about ALR are trivial or false, or both, and they tend to obscure the most interesting contributions in specific texts by individual Realists (GJB, ch.5)); ${ }^{30}$ (e) in teaching jurisprudence, concentration on classic ALR texts can distort the contemporary significance of realism. ${ }^{31}$ In short, discussions of "realism" today need to be de-parochialised and updated.

6. Labels and concepts. Labels such as "Realism," "realism," "sociology of law," "Law in/and Society," "law in context" should not be expected to do much work as concepts, especially not as conceptions of law. They are best treated as rough and overlapping designations of fields of enquiry or approaches. However, "realism" has an important role to play in jurisprudence as a hedgehog concept.

${ }_{27}$ On Llewellyn's unfinished agenda (see GJB, ch. 6 and Afterword, 438-443). On Underhill Moore, see below, 138 .

${ }^{28}$ KLRM, ch. 15 discusses ALR texts that were still worth reading in 1973. Today, one can treat some of these as being mainly of historical interest. Some realist texts survive because they are soft targets, even if they were retracted or modified. This includes some statements in Frank's Law and the Modern Mind (1930) (generally ignoring Courts on Trial (1949)) and Llewellyn's famous two rash statements in The Bramble Bush (1930), which continued to be used as a target after he had retracted it in 1951, most influentially by Hart (1961, ch. 6). Hart later discreetly retracted in "The Nightmare and the Noble Dream" (Hart 1983, 128), but Hart's retraction has also been ignored by some later commentators.

29 On implications of transnationalization for realist approaches, see my Thesis 10. From its inception NLR has included transnationalization as one of its central concerns (e.g., Garth 2006; Merry 2006; Suchman and Mertz 2010).

${ }^{30}$ In particular, the idea that ALR was exclusively concerned with adjudication on contested or hard questions of law deserves to be seen as both in respect of ALR, but more importantly as an account of adjudication in general rather than of rarified appellate adjudication. It suggests a tendency within ALR and among commentators also to succumb to the gravitational pull of the doctrinal concept of law, the very tradition that realists were reacting against. At least Llewellyn acknowledged in The Bramble Bush that by focusing on appellate cases he was capitulating to "the threat of the available" (Llewellyn 1930, 102-104). Reasoning about questions of law and questions of fact (a problematic distinction) and other practical reasonings are, of course, involved at many stages of litigation (not just in courts) and in other legal practice contexts. See below note 51.

${ }^{31}$ There is an abundant literature to choose from. Some papers in this book might serve the purpose. Some chapters of Hanoch Dagan's challenging book Reconstructing American Legal Realism and Rethinking Private Law Theory (2013) or one of his shorter essays, e.g., "Law as an Academic Discipline" (forthcoming) would serve to bridge the gap between classical ALR and contemporary concerns. However, in my view the key question for students should be: what is involved in being realistic about law today? In considering possible answers, teachers need to break free from ALR texts. 
In 1929-1930, the label "Realism" probably served its purpose as a contrast to an ill-defined "formalism." It was rhetorically effective: punchy, macho, and openended: Real Men realistically depicting Real Law in the Real World (i.e., the United States). Perhaps fortunately, perhaps not, commentators have not generally taken "R/realism" as a concept very seriously in this context. On the whole, they have related it to vague, commonsense understandings of "the law in action" (another macho term $)^{32}$ or legal practice or legal practices. Like jesting Pilate they have not stayed for an answer. But if we did try to tease out a core meaning, we would be entering a philosophical ${ }^{33}$ and aesthetic morass. For example, in art history "realism" has variously been interpreted to refer to at least ten different ideas (Osborne 1970). It might possibly be fruitful to locate some particular ALR texts as analogous to one or other of these, but it is unlikely to be helpful to interpret ALR in general in terms of such analogies. At most, it would further underline the diversity of ALR.

However, realism as interpreted here has a contribution to make to jurisprudence, not as a theory of or about law, nor as a rounded philosophy of law, nor as a rival or subverter of analytic, idealist, or doctrinal approaches, but rather as one integral part of understanding law. In this view, it is best treated as a hedgehog concept; that is, it stands for one Big Idea - the importance of the empirical dimensions of law and justice as part of understanding law. ${ }^{34}$ Once that proposition is accepted, the gates open to all of the foxy diversity, controversy, differing traditions, and dilemmas and problems within empirical legal studies. ${ }^{35}$

${ }^{2}$ The term "law in action" is useful as a broad term designating a focus on empirical aspects of law as social fact. But its vagueness is revealing. Leaving aside the indeterminacy of "law" in this context (what is in action?), what does action encompass? Surely it need not be limited just to behavior (e.g., Black 1976, 1995) or attitudes, but also beliefs, values, techniques, skills, knowledge and opinion about law, unintended consequences, impact, etc. Can there be action and agency without meaning? Are not rules important sources of meaning? Whose action? Surely not only appellate judges: that would be clearly unrealistic both about the tasks of judging and about other law-related actors, subjects, and victims: e.g., law-makers, law interpreters, appliers, expositors, enforcers, users, avoiders, evaders, plaintiffs, claimants, deviants, regulators, inspectors, regulators, and observers - individuals, legal persons, and collectivities (see also above note 30). On the much-debated distinction between "the gap" between law in books and law in action, see GJP, 318-320; Nelken, 981). One aim of realist and contextual approaches has been to get more of the action into the books. This has been one of the main aspirations of the Law in Context series since 1970.

33 "Real" as opposed to what? Artificial (posited?), fake, false, deluded, unreal, imaginary, nominalistic, aspirational, ideal, speculative? Does it encompass virtual reality, magic realism, multiple realities, irrealism? Does commitment to a realistic perspective imply a particular epistemology, such as Susan Haack's "innocent realism"? (Haack 1998; GJB, ch. 9). Can a Rortyan post-modernist also be a "realist"? (GJB, 293-295; Rorty 1991). Did Dworkin think that he was being realistic? And so on. My own epistemology is close to Haack's, but the claim that realism about the law in action is important or necessary as part of understanding legal phenomena does not necessarily imply a particular epistemology, even for non-cognitivists. Rather it is mainly a matter of focus.

34 "The fox knows many things, but the hedgehog knows one big thing." The allusion refers to a distinction drawn by Archilocus, and popularized by Isaiah Berlin (1953). Ronald Dworkin's last major work was entitled Justice for Hedgehogs (2011); see above note 14. His hedgehog idea concerns the unity of value, the central tenet in his moral theory.

35 On some standard dichotomies and tensions within the social sciences see GJP, $258-262$. 
Berlin's (1953) metaphor of the hedgehog and the fox is easily overused. ${ }^{36}$ In respect of individual thinkers, it can at best indicate tendencies between two poles or ideal types representing universality and particularity, which are relative matters, with most thinkers and theories moving up and down multiple ladders of abstraction with differences of emphasis. Realism as a hedgehog concept represents one key aspect of an approach that in practice tends towards the particularistic. It also reflects recent debates about Realism and Idealism: how far can and should philosophy, especially moral philosophy, engage with "real life" problems?37

7. New Legal Realism (NLR) is presented by its leaders as primarily an activist movement concerned to integrate empirical legal studies in concrete ways into academic legal practice, especially law teaching and legal scholarship. It is out to change what academic lawyers do and to foster empirical legal approaches rather than make any sustained contribution to jurisprudence.

To an outsider "the New Legal Realism" seems to be a lively, fast-moving, and stimulating movement. It is admirably open-ended and, for that reason, difficult to characterize or generalize about. One hopes that it will not be bedeviled by futile debates about its scope and meaning. For the immediate purpose, it will suffice to set up an ideal type of statements and claims about the movement, based on statements by Mertz (especially, 2016); Macaulay and Mertz (2013); Macaulay (2005); and Suchman and Mertz (2010).

What kind of "ism" is NLR? It is fairly clear what it is not: (i) it is not a theory of or about law, nor does it assume a particular conception of law; (ii) it is not a philosophy of law; (iii) it is not an alternative or rival to other perspectives, such as natural law or moderate versions of positivism; ${ }^{38}$ (iv) it does not give a precise or specific meaning to the term " $\mathrm{R} /$ realism"; ( $\mathrm{v}$ ) its orientation is empiricist in a broad sense, but it is open-ended about perspectives, methods, and focuses of attention. In particular, it is not confined to the study of adjudication (in a broad or narrow sense), and it encourages "bottom up" (ground-level) standpoints, among others; (vi) it is not merely a continuation of classical American Legal Realism; ${ }^{39}$ (vii) it is not

$3^{6}$ The hedgehog/fox distinction has been used less appropriately by Brian Simpson in characterizing himself as a fox and Herbert Hart as a hedgehog. Neither characterization works well (see Kritiosis and McCrudden 2012, passim).

37 On Amartya Sen as realist, see below note 53.

$3^{8}$ There may be a tendency for realist work to assume some positivist conception of law, in the sense of distinguishing law as it is and law as it ought to be in some contexts, in my view often for good reason (GJB, 107-111; cf. Leiter 2007, 60. See further below note 42 and accompanying text). But that is not a necessary condition for being "realistic." Insofar as this paper argues for the integration of conceptual, normative, and realist perspectives, it assumes that moderate forms of conceptual analysis (but not replacement naturalism) and of normative or ideal theory are reconcilable with moderate realism. Dagan (2013b) makes the case that his reconstruction of ALR is incompatible with positivism. This is a debate for another occasion.

39 Insofar as it has intellectual forebears, it follows on from the aspirations of the "scientific wing" of ALR and the Law and Society Movement, but wishes to break free from the narrowing constraints of debates 
puristic about scientific rigor, but echoes Llewellyn's dictum that "knowledge does not have to be scientific, in order to be useful and important" (Llewellyn 1941, 22; KLRM 188-193). It recognizes the constraints on feasibility and sustainability of rigorous empirical research.

It is less easy to generalize about NLR - that is one of its strengths. One may say: (i) it is strongly multi-disciplinary and interdisciplinary and sensitive to the difficulties of this kind of scholarship and theorizing; (ii) its research agenda is open-ended, but so far it has been mainly concerned with legal phenomena in the United States; (iii) the top priority of its educational agenda to date is to stimulate and facilitate the translation and integration of empirical research findings into mainstream courses in American law schools; (iv) one of its main concerns is how to translate and use findings of empirical research, especially social scientific research, into the academic language and culture of academic law; (v) it is activist at a practical level both in providing training in methodology and sensitizing mainstream academic lawyers to the relevance of empirical legal studies to their practices; (vi) much of its focus is on quite specific problems within or across sub-disciplines. NLR makes few general theoretical claims. ${ }^{4}$

If this is a fair interpretation of NLR to date (and as it is presented in this volume), it is quite compatible with the argument of this chapter.

\section{Legal Realism as Jurisprudence}

8. R/realism needs to be recognized as contributing to general and particular jurisprudence, but not as advancing a distinctive theory or conception of law.

Many sociolegal scholars are skeptical of the value or relevance to their work of analytical legal philosophy and much other mainstream jurisprudence. As it is currently practiced, there is some merit in this view, especially in respect to some of the more abstract kinds of philosophizing. Some draw on social theorists, many of whom were not specifically interested in law. Some spurn explicit theorizing. It is part of the thesis of this paper that if empirical legal studies are to become more central within the discipline of law, jurisprudence needs to be taken seriously by sociolegal scholars, for doctrinal legal theory marginalizes their activities.

NLR does not claim to produce a distinctive jurisprudence, but Brian Tamanaha (2013) has suggested one way of drawing together various strands, including NLR, into "sociolegal theory" as a "Third Pillar" of jurisprudence. ${ }^{41}$ I am sympathetic to

about ALR as an historical phenomenon (see above Thesis 5). In one sense it may be seen as continuing the unfinished agenda of "scientific" ALR, but its goals are broader than that.

$4^{\circ}$ One exception is that "New Legal Realists in the U.S. have been working towards a new synthesis of law, social science and policy since 1997" "New Legal Realism Conversations: An Empirical Law and Society Blog" 2011). That sounds like an ambitious theoretical agenda along somewhat different lines from what is suggested here. My impression is that to date NLR has had more concrete aims.

$4^{1}$ Tamanaha rightly suggests that background assumptions or orientations do not on their own constitute a theory of law (Tamanaha 2013). He argues that there is a broad tradition of theorizing about "law and society" out of which a general socio legal theory can be developed with a distinct name and identity 
the thrust of his argument, and I agree that historically positivism, natural law, and social-theoretical approaches have been perceived as rivals. However, I suggest that the most useful interpretation of realism, and more broadly of social-legal theory, should be restricted to some clear central theoretical claims or propositions, without adopting any particular conception or theory of law. ${ }^{42}$ There are two main reasons for this: first, adopting such a theory or conception of law would be unnecessarily restrictive - a realist approach opens the door to the whole range of social theories and perspectives. The concept of law should not be expected to do much work. Second, and more important, realism and social-legal theory, as interpreted here, should not be seen as rivaling or merely complementing other strands in legal theorizing, but should rather claim that they are an integral part of understanding law and so of the discipline of law. This involves denying sharp divisions between theoretical schools or traditions. The central claim of realism relates to focus, not epistemology or methodology or ideology: any theory or general theoretical approach that neglects or excludes the empirical dimensions of our discipline is deficient. Nevertheless, too much is conceded to narrow visions of jurisprudence or legal philosophy unless one takes the theoretical aspects of realism seriously.

The main concerns behind realism, including NLR, relate to what academic lawyers do, or should be doing, in their roles as scholars and teachers. ${ }^{43}$ Given this primary focus, it has not been a priority to contribute to the more abstract levels of legal theorizing. ${ }^{44}$

9. R/realist claims can be expressed in weak, moderate, or strong terms and can be elaborated in more or less detail. Here one proposition will suffice: knowledge

that can concretize it as a focus of attention. He leaves open whether this should be treated as a contribution to abstract legal philosophy or just as a distinctive strand/tradition and branch of jurisprudence. Hanoch Dagan has developed a sophisticated, new "Realist" synthesizing "theory of law" based on some classic ALR texts (Dagan 2013b). I find it very illuminating, but it looks like a new Dagan theory inspired, inter alia, by ALR, rather than just a rational reconstruction. Although claiming to be transnational and not confined to adjudication, in its present form it has an American bias and devotes a lot of attention to appellate judicial decisions and reasoning on questions of law. It is also constrained by a felt need to be true to the classic texts, at least in spirit. If Dagan's theory of law broke free from such constraints, it is quite close in spirit to this paper. However, Dagan sees such a distinct synthesizing theory as a necessary foundation for a "realist" approach. I differ. By limiting my interpretation of "realism" to a single proposition that is compatible with many such theories of law, but incompatible with exclusive doctrinal theories, my intention is to suggest that accepting the hedgehog thesis involves no necessary commitment to particular positions in the canon of jurisprudence or social theory; but it does rule out exclusivist doctrinal theories, which at present represent the bulk of legal theorizing.

$4^{2}$ Cf. MacCormick $(2007,300)$ (claiming that his institutional theory fits better with empirical understandings than most rival theories and that some conceptual claims are not refuted merely by a lack of fit with empirical evidence). I am grateful to David Restrepo-Amariles for this point. Hanoch Dagan argues strongly against a positivist interpretation of R/realism (Dagan 2013 b). Of course, much depends on how "positivism" is used in this context. On indicators and league tables requiring a working is/ ought distinction, see below note 65 .

43 On particularism, see below note 60 and accompanying text and references.

44 On whether most American Realists were "positivists" see above note 38. 
and understanding of the empirical dimensions of law and justice are relevant to/ part of (weak), an integral part of understanding legal phenomena (moderate), necessary/essential (strong) to the enterprise of understanding law and legal phenomena.

General "realist" claims can be roughly designated as weak, moderate, or strong, but there is room for differences about such labeling. For example, in my view it is weak to say that Salmond was incomplete; it is moderate to say, in the context of my legal education, that it was misleading; it is strong to say his treatment of negligence was invalid, or false, or an example of academic malpractice. Similarly, to say that some legal rules are indeterminate is weak; to say that legal rules generally need to be interpreted in context, or that for most scholarly and practical purposes knowledge of legal rules or legal doctrine is not enough, is moderate; to say that "talk of rules is a myth" or that all rules are indeterminate is strong. ${ }^{45}$

\section{(a) Even weak versions of this proposition can play a useful role. For it is sufficient to challenge any theory or perspective that implicitly or explicitly denies it.}

For example, it challenges the idea that it is possible to divine the nature or essence of law solely by conceptual analysis, as some analytical jurists suggest (e.g., Raz 2005, 324; discussed by Dworkin 2006b, ch. 8; Raz 2009, 104-105; discussed by Tamanaha 2013; cf. Shapiro 2011). ${ }^{6}$ Similarly, it challenges even weak versions of Dworkin's interpretations of "the sociological concept," let alone the silly suggestion that sociolegal perspectives are neither philosophically interesting nor practically important. Indeed, it challenges all strong forms of doctrinal theorizing about law.

(b) Moderate versions of realism can add some specificity to realist theoretical claims even at this general level.

Some of these have been touched on already. For example:

(i) For most purposes the study of doctrine alone is not enough; ${ }^{47}$ for example, the claim that one cannot understand the law of negligence or personal injuries in England or the United States without taking into account insurance, settlement out of court, the vanishing trial, and the damages

45 See below page 137 .

$4^{6}$ One does not even have to subscribe to Leiter's strong (replacement) or a weak version of naturalism to deny the possibility or, if possible, the value of such quests (Leiter 2007, ch.1). This debate is primarily a philosophical one. My position is that, whether or not it is feasible to pursue abstract conceptual analysis without regard to social facts, this kind of philosophy is not very helpful to those pursuing empirical enquiries about law at lower levels of abstraction.

47 A standard elaboration of this proposition points out that legal rules are not self-enacting, selfinterpreting, self-applying, self-invoking, or self-legitimating (GJP, 299-301). They need to be studied "in context" - what context is appropriate itself depends on the context of enquiry. Even a single, discrete rule is nearly always part of a complex of understandings, which may include not only other rules and rules about rules, but also other factors. Galligan's conception of "social spheres" usefully captures one central idea (Galligan 2007, ch.6; cf. GJP, 298-301, 320-321). What is enough depends on context. Of course, scholarly enquiry is in one sense never complete. 
lottery. ${ }^{4}$ A purely doctrinal treatment is not only incomplete; in some contexts it will also be misleading. Legal doctrine needs to be studied and interpreted in context. Conversely, an account of extra-judicial settlements of personal injuries claims normally presupposes an accurate account of relevant doctrine.

(ii) Many enquiries about legal phenomena at whatever level of abstraction involve a combination of conceptual, normative, and empirical strands. For most scholarly and theoretical purposes, conceptual, normative, and empirical enquiries are interdependent, but there is room for differences and disagreements about emphasis in particular contexts. ${ }^{49}$

(iii) As was argued above, realism as an approach and as part of jurisprudence cannot be sensibly confined to being realistic about adjudication, let alone decision making by superior common law courts. ${ }^{50}$

(iv) A prime target of moderate legal realism is the use of the term "legal reasoning" to apply it only to reasoning about questions of law, and the practice of neglecting all other kinds of reasonings in legal contexts (such as reasoning from evidence in court, evidence-based policy and law making, reasoning in sentencing, and reasoning in negotiation) and the relations between them (RE, ch.10). ${ }^{1}$ This usage is an egregious and impoverishing example of the gravitational pull of doctrine.

$4^{8}$ A realist approach often involves the reclassification of a topic or organizing category, e.g., Patrick Atiyah's substitution of compensation for accidents for negligence (Atiyah 1970). On "fact-based classification" see Jolowicz (1970).

49 This does not involve commitment to claims that empirical information is always relevant to conceptual analysis or normative judgments. I am somewhat sympathetic to the view that: "We cannot certify the truth of our value judgments through physical or biological or metaphysical discoveries. We must make a case, not supply evidence, for our convictions" (Dworkin 2011, 418). I would insert "only" before supply (and see note 55 above). Also see discussions of evidence-based policy, challenging the view that empirical evidence can ever be enough. E.g., Black (2001): "Evidence-based policy" grew belatedly from evidence-based medicine. See the website of the group The Coalition for EvidenceBased Policy, www.coalition4evidence.org, and especially http://coalition4evidence.org/1399-2/ national-academy-of-sciences-report/. In the U.K., see Solesbury (2001). See also Russell and Greenhalgh (2011), and Cartwright and Stegenga (2011).

50 See above note 22.

51 Another ladder of abstraction illustrates the point: questions about rationality, reasoning in general (logic in a broad sense), and practical reasoning in general are principally philosophical questions; questions about reasoning in legal contexts, reasoning at all stages of litigation, and reasoning about questions of law in appellate courts are abstract jurisprudential questions that require both philosophical and legal knowledge (including some knowledge of different legal traditions at this level of generality); questions about reasoning in hard cases in common law jurisdictions or in American appellate courts in a specified period or the U.S. Supreme Court in a specified period, down to analysis of the reasoning in a single judicial opinion in the United States or elsewhere, all need significant amounts of local legal knowledge. Only questions of law are regularly treated by doctrinal legal philosophers and jurists under the loose rubric of "legal reasoning," often moving freely among levels of abstraction. Interestingly, some of the more abstract aspects of reasoning in legal contexts, for example the probabilities debates in regard to proof, are particularly philosophically interesting (RE, 126-131, 332-334; Roberts and Zuckerman 2010, 116-132). Quite often in the literature on "legal reasoning" the distinction between questions of fact and questions of law is treated as if it is 
(v) Although analytical positivists like Hart have adopted social-fact conceptions of law, they have tended to draw back from taking social facts seriously (GJP, 58-60; Lacey 2006, 2013). Analytical jurists have not devoted much attention to socio legal concepts such as function, fact, dispute, process, institution, and even judge, lawyer, and court, even though describing, interpreting, comparing, generalizing about, and explaining legal phenomena are as much in need of adequate concepts as legal doctrine and its presuppositions (GJB, ch. 2; Twining 2005). ${ }^{52}$ I have argued elsewhere that there is plenty of work for conceptual elucidation across the doctrinal/empirical divide, especially in relation to empirical comparative legal studies/comparative law (GJP, ch. 2 and 8).

(vi) Amartya Sen's approach to justice and injustice (Sen 2009) can be interpreted as an example of moderate realism. His complaint against a tradition of philosophizing and economic theory ("transcendental institutionalism" exemplified by Rawls' theory of justice) is that it is too abstract and removed from what actually happens to be of practical use. ${ }^{53}$ Sen's plea is for being "constantly sensitive to what actually happens in the world" (Sen 2009, 85). The objection is not that transcendental theory is valueless or uninteresting, but rather that too much philosophical effort has been diverted from making useful contributions to pressing real-world actual problems that are soluble. Put crudely, from a practical point of view, ideal theory is neither necessary nor helpful (Sen 2009, 24-27). Sen clearly is a "realist" in the present context, and many realists will be attracted by the spirit of his approach, but acceptance of the core idea of realism does not necessarily commit a legal realist to prefer Sen's theory of justice to that of Rawls.

My thesis is that moderate versions of realism, as interpreted here, are compatible with moderate versions of natural law, or analytical positivism, ${ }^{54}$ or a Dworkinian

unproblematic. This obscures the relationship between reasoning from evidence and reasoning about questions of law, and the similarities and differences between them - for example, the role of stories in the two overlapping types of argumentation not only in adjudication, but in decision making in other kinds of legal context.

52 Besides elucidation, conceptual analysis can help in disambiguating, deconstructing, constructing, refining, and inventing usable concepts, not least in regard to concepts that can transcend legal traditions and cultures. On the emics/etics debate in anthropology (Headland, Pike, and Harris 1990) and its significance for jurisprudence and comparative law, see GJP (n. 41, n. 63, n. 48, and n. 98).

53 The crux of his thesis is summed up as follows: "There are ... good evidential reasons to think that none of these grand institutional formulae typically deliver what their visionary advocates hope, and their actual success in generating good social realizations is thoroughly contingent on varying social, economic, political and cultural circumstances" (Sen 2009, 83). And see the more general debate, stimulated by thinkers like Bernard Williams (1985) and Raymond Geuss (2001), concerning an alleged lack of realism in much recent political philosophy in Hall (2013); Floyd and Stears (2011).

54 A realist can agree that describing, comparing, generalizing about, and explaining legal phenomena often raise difficult issues of conceptualization, that these activities need serviceable concepts, and that rigorous conceptual analysis can help in constructing and refining such concepts (GJP, ch. 2). 
view of public morality, ${ }^{55}$ or idealistic views of human rights or expositions of doctrine that are sensitive to context. No doubt some of these moderate claims will be considered controversial.

\section{(c) Strong claims}

Strong claims for realism are likely to be controversial just because they do, or seem to, challenge strongly entrenched positions. Some extreme claims for realism can be shown to be false or so overstated as not to be worth defending, but others can be interpreted to be interesting and worth debating.

Let us take two standard examples of "extreme" views attributed to R/realism: first, "Realists advance a prediction theory of law." This is a loose attribution that is generally discredited. It is widely accepted that such a theory is easily criticized on several grounds and that Hart did a good job of demolishing it (Hart 1961, 10-12, 86-88, 133-135). The main criticism of Hart in this respect turns on whether any ALR can be charitably interpreted as seriously advancing such a theory. On the other hand, it is also widely acknowledged that one of the main tasks of several kinds of legal actors is to predict various kinds of decisions and other outcomes, and that doctrine can be one aid, but not the sole one, for making such predictions from certain standpoints. Realists made a contribution by emphasizing that predicting is one thing that legal actors do, but that is not a theory of law. Such a moderate interpretation leaves only a little room for worthwhile controversy, but plenty of room for refinement.

Second, the Realists believed in "rule-scepticism or the claim that talk of rules is a myth" (Hart 1961, 133). There is a fairly wide acceptance that no Realist ever made such a claim, but that by distinguishing the concepts of rule from command, habit, and prediction Hart destroyed the idea. The original statement is ambiguous, but if in the present context we interpret it to be a denial that rules exist as social facts, it may be worth revisiting the debate.

The caricature of ALR that Hart attacked might still be defensible philosophically. ${ }^{6}$ If we turn to the general theory of norms, the position is more controversial

55 For example, a Dworkinian can acknowledge that actual consequences may sometimes be relevant to making the right moral decision. A moderate Dworkinian can acknowledge that empirical legal studies have a role to play in the discipline of law, though not necessarily in respect of narrowly posed issues about the relationship between legal and moral propositions. I leave to one side the general issue whether all theorizing necessarily involves empirical assumptions.

${ }^{56}$ In 1977, Ronald Dworkin corrected a statement that he had made in an earlier article as follows: "My point was not that 'the law' contains a fixed number of standards some of which are rules and others principles. I want to oppose the idea that 'the law' is a fixed set of standards of any sort. My point was rather that an accurate summary of the considerations lawyers must take into account, in deciding particular issues of rights and duties, would include propositions having the form and force of principles, and that judges and lawyers themselves in justifying their conclusions, often use propositions which must be understood in this way" (Dworkin 1977, 76; reaffirmed Dworkin 2013b, 234, $264 \mathrm{n}$. 6). I shall not consider here whether this makes Dworkin a "rule-skeptic" (rules play a modest role in his theory), but it is clearly a rejection of positivist views that propositions of law can be separated conceptually from their justifications. I am indebted to Andrew Halpin for this point. Some strong versions of radical indeterminacy in respect of rules may be interpreted as a denial of their existence. 
than some jurists might expect. There is no uniformity of usage across disciplines of "norm," "rule," or "social norm" in normative theory (Twining 2011a, 479-485). Nor is there any settled way of classifying them. There are serious problems about individuation of norms and of normative orders. There is no consensus on the question: "under what conditions is it true to say that a rule exists?"57 There is still no consensus within jurisprudence as to this question in relation to legal rules. Jurists have tended to skirt these questions (Joseph Raz (1990; 1992, 70-92) is a notable exception), concentrating on "the legal" in "legal rules" or treating them as a species of institutional facts (e.g., MacCormick 2007) or fictitious entities (e.g., Bentham's theory of fictions, discussed by Quinn 2015; Schofield 2006). None of these puzzles has stopped several self-proclaimed "realists" from writing whole books about rules (e.g., Llewellyn, The Theory of Rules (ed. Schauer 2011); Schauer, Playing by the Rules (1991); Twining and Miers, How To Do Things with Rules ([1973]2010)) or making or criticizing legislation, or arguing that certain rule-statements are inaccurate, false, or debatable. It is almost impossible for a jurist or social scientist to do without the language of rules.

Let us consider another example of strong realism. Underhill Moore raised the question: can there be a general empirical science of law? (e.g., Moore and Callaghan 1943) $.5^{8}$ What exactly the question means needs clarification. Moore's answer was based on crude versions of behaviorism and "science" current at the time and has generally been dismissed. His parking studies, carried out amateurishly and based on a contested version of "learning theory," were ridiculed and generally ignored. (Schlegel 1995, ch. 3 is a fairly sympathetic assessment.) But the idea that how human beings interact with and respond to rules is an important line of enquiry as part of a general empirical science of law. The idea is again topical in the light of "globalization" (GJP, ch. 8.9). Moore's basic question could be interpreted to mean: can empirical enquiries produce (some) explanatory, falsifiable, evidence-based, predictive, cumulative hypotheses and generalizations about legal phenomena in the world as a whole that are comparable in rigor to some findings of hard behavioral or physical sciences? Is such a "science" feasible? Is it desirable? In my view, we have hardly started to pose such questions, let alone tried to answer them (GJP, $258-262) .{ }^{59}$ Both the questions and the answers are contestable and deserve the attention of legal theorists.

57 My own view is that is useful, indeed often necessary, to talk as if rules exist as social facts (but social facts are themselves constructs) - and that it makes sense to treat legal rules as institutional facts. However, I do not pursue that hare here.

$5^{8}$ Cook (1927) discussed a similar question from a different standpoint (KLRM, 36-40).

59 In my view, the main lessons of ALR in this respect are that Underhill Moore and others took the analogy with the physical sciences too literally and they radically underestimated the enormity of the enterprise of developing a new science (see also KLRM, 188-196). Llewellyn, whose views on this seem to me to be eminently sensible for the time, asserted that the social sciences generally were at a "prepre-science stage" (Llewellyn 1941, 13; discussed KLRM, 191-192). On justified and unjustified resistance to "scientism," see GJP, ch. 16.4 at www.cambridge.org/twining. 


\section{Implications of "Globalization"}

10. Globalization and transnationalization present major challenges to legal realism, not least in respect of developing evidence-based generalizations about law throughout the world or substantial parts of it.

Academic law, especially doctrinal studies, like most of our heritage of legal theory has in the past been almost exclusively concerned with the municipal law of sovereign states treated as self-contained units. Transnationalization, regionalism, and so-called globalization are rapidly changing the agendas for our discipline and for legal theory. We have to concern ourselves with a much wider range of legal forms - at transnational, regional, supranational, and even global levels. Fields such as comparative law, new forms of international law, internet law, and new forms of domination and imperialism now demand attention of legal scholars and jurists. So do concepts such as nonstate law, soft law, normative and legal pluralism, diffusion, and terrorism. The legacy of ALR and other "realisms" is almost certainly inadequate to deal with many such issues. NLR is taking up the challenge.

Joseph Raz, in a passage quoted by Tamanaha acknowledges that sociology of law, ${ }^{60}$ "provides a wealth of detailed information and analysis about the functions of law in some particular societies" (Raz 2009, 104-105; Tamanaha, 2013). Raz suggests that this is irrelevant to legal philosophy, which "has to be content with those few features which all legal systems necessarily possess" (Raz 2009, 105). This is a fair acknowledgement of the main past achievements of empirical legal studies, and it correctly emphasizes the tendency towards particularism of such approaches: just as doctrinal studies have historically focused almost entirely on the municipal legal systems of particular modern nation states, similarly empirical legal studies have focused primarily on large and small "societies" treated as self-contained units. However, Raz's statement is out of date on this in one important respect. In the last twenty years or so, both doctrinal and empirical legal studies have broadened out geographically, perhaps largely in response to so-called globalization. Transnational and comparative empirical legal studies are coming into their own (GJP, passim, esp. 234-258). ${ }^{61}$ As a result, we are at a very early stage in developing the capacity to take on big theoretical issues and bold empirical hypotheses from a genuinely global perspective. ${ }^{62}$ For example, are we ready to tackle such questions as:

${ }^{60}$ A charitable interpretation treats "sociology of law" here to cover empirical legal studies generally including macro- (e.g., Glenn 2007) and micro- legal history (e.g., Hurst 1964). Raz and I differ on the scope and value of philosophy of law.

61 A significant recent development is the series on Legalism, published by Oxford University Press. This series promises to provide concepts and hypotheses that could greatly advance the empirical side of comparative law. The first volume, Paul Dresch and Hannah Skoda (eds.) Legalism: Anthropology and History, was published in 2012.

${ }^{62}$ Because of the traditional focus on local municipal law "[a]t this stage in history we are not yet very well-equipped to provide an over-arching Grand Theory or even many reliable generalisations about the hugely complex phenomena of law in the world as a whole: as yet we lack concepts, data, hypotheses and models adequate for the task. Our Western academic heritage provides some 
To what extent and under what conditions is law context- and culture-specific? ${ }^{63}$ Can there be a general scientific empirical theory of legal phenomena in the world as a whole? (GJP, ch. 11).

What role does law play in advancing or constraining sustainable economic and social development?

These are examples of the kind of challenges that confront jurisprudence when one adopts a global perspective. As the next volume will be devoted to NLR and globalization, it would be premature to comment in detail here, except to emphasize that extensive conceptual, normative, and empirical work will be necessary to de-parochialize some aspects of realistic approaches. ${ }^{64}$

\section{Indicators and rankings: An even newer "realism"?}

We live in audit societies and an increasingly, often dubiously, audited world, including more or less crass league tables based on dubious comparators (Power 1997; GLT, ch. 6). Assessing how far reality falls short of aspiration and suggesting ways to close the gap in respect of democratic deficit, respect for human rights,

promising starting points on which to build, but the challenges are enormous. The message is antireductionist: it emphasises the complexity of legal phenomena and warns against simplistic, exaggerated, false, meaningless, superficial, and ethnocentric generalisations about law in the world as whole [or large parts of it]" (GLS, 18-19).

63 Cf. Bentham's typically acute formulation in an early work: "To give the question at once universal form, what is the influence of the circumstances of place and time in matters of legislation? What are the coincidences and what the diversities that ought to subsist between laws established in different countries and at different periods, supposing them in each instance the best to be established?" (Bentham," Place and Time" (1780), in Engelmann 2011, 152-219; discussed GLS, 59-67; also cf. Tamanaha 2013, 6.).

${ }^{6}$ On NLR treatments of globalization see above note 29. I have written extensively about the implications of "globalization" for the discipline of law (see especially GLT; GJP; and GLS). As a starting point it is worth bearing in mind some standard warnings: (i) do not restrict "globalization" to processes and phenomena that are genuinely world-wide: most significant transnational patterns in relation to law are sub-global; (ii) do not overuse such terms as "global law," "global lawyers," "global solutions," "global values"; (iii) taking "globalization" seriously challenges some mainstream general assumptions underlying Western traditions of academic law: it is not a great exaggeration to say that adopting a genuinely global perspective suggests that our academic cultures have tended to be state-oriented, secular, positivist, "top-down," Northocentric, ignorant of other traditions, unempirical, and universalist in respect of morals. To date empirical legal studies may have been less vulnerable to some of these charges than orthodox doctrinal approaches (e.g., in regard to pluralism, nonstate law, and empiricism), but insofar as they have been largely focused on "societies" treated as if they are selfenclosed units a good deal of rethinking and adjustment is needed. Anthropologists have moved away from this practice, mainly since a seminal conference at Bellagio in 1986, where they rediscovered history and geography (see GJP 42-43 and Starr and Collier 1989); (iv) "globalization" should not be thought of as a threat to detailed, particular, practical, and scholarly legal studies. In GLS I have suggested an approach for individual scholars and teachers to ask in an open-ended way: what are the implications of "globalization" for my specialism, my course, my research project? For many individuals a reasonable answer may be: "not much." After all, most legal studies are rightly oriented to local, practical, particular problems. 
attraction of foreign investment, social protection and employment, business regulation, corruption, and the rule of law is now a major and rapidly expanding industry. "Indicators" articulating normative standards in respect of official laws, enforcement, efficacy and efficiency, impact, and so forth have been developed with increasing sophistication, ${ }^{65}$ amid considerable controversy, at national, regional, ${ }^{66}$ transnational, and global levels (Davis, Kingsbury, and Merry 2012; du Marais 2006). They include the Millennium Development Goals, the Rule of Law Index, Doing Business Indicators, European Union indicators in the framework of the Open Method of Coordination, United Nations Rule of Law Indicators, and the World Bank's World Governance Indicators, as well as human rights conventions and declarations. All of these require a working distinction between aspiration (ought) and reality (is) - with "reality" operating at various levels (see GJP, 251-258, 296-301, 348-355 - now partly outdated - and Restrepo-Amariles, forthcoming). So far, apart from a few enclaves in respect of human rights and development programs (Davis, Kingsbury, and Merry 2012) academic lawyers have focused almost entirely on relatively sophisticated (though self-interested) critiques of law school league tables (GLT, 161-165, GJP 254-255). The general phenomenon of indicators and rankings is one of the principal current challenges to academic law, including jurisprudence. Adequate critique and, where appropriate, development require normative, conceptual, and empirical inputs. To what extent do current ones measure acceptable aspirations, let alone realities, of the law in action? One reason why jurisprudence should be interested in indicators is to understand the extent to which legal phenomena and the discipline of law may be under pressure because of these phenomena.

\section{CONCLUSION}

Legal realism needs to be integrated into mainstream jurisprudence. Insofar as doctrinal legal theory excludes or marginalizes empirical dimensions of law and justice, it impoverishes the enterprise of understanding law.

65 "Indicators reflect the evolution of social science research in which not only we have more data (empirically collected) but also a more sophisticated use of it (through the use of econometrics, mathematics, statistical methods, etc.). There is thus an important difference from classic statistics in the sense of collection of empirical data about the number of judges, with contemporary indicators, which provide a more complex view of phenomena at different levels: classification of phenomena, quantification, mathematization, etc." (David Restrepo-Amariles, private communication to author, September 2013). I am grateful to him for help with the whole of this paragraph.

66 On the regional level, "Indicators are a key component of the Open Method of Coordination of the European Union. Here indicators are clearly used to design and assess regulatory standards in areas such as education, social protection, employment, etc. ... in areas where the European Union has no law-making competence" (David Restrepo-Amariles, communication to author, September 2013). 


\section{REFERENCES}

American Academy of Arts and Sciences. 2013. The Heart of the Matter: Report of the Commission on Humanities and Social Sciences. Cambridge, MA: American Academy of Arts and Sciences. http://www.amacad.org.

Atiyah, Patrick S. (1970) 2013. Accidents, Compensation and the Law, $8^{\text {th }}$ edition (with Peter Cane). Cambridge, UK: Cambridge University Press.

Atiyah, Patrick S. 1997. The Damages Lottery. Oxford: Hart Publishing.

Bentham, Jeremy. (1780) 2011. "Place and Time," edited by Philip Schofield and Stephen Engelmann. In Selected Writings: Jeremy Bentham, edited by Stephen G. Engelmann, 152219. New Haven: Yale University Press.

Berlin, Isaiah. 1953. The Hedgehog and the Fox: An Essay on Tolstoy's View of History. London: Weidenfeld and Nicolson.

Black, Donald. 1976. The Behavior of Law. London: Academic Press.

Black, Donald. 1995. "The Epistemology of Pure Sociology." Law and Social Inquiry 20: 829-870.

Black, Nick. 2001. "Evidence Based Policy: Proceed with Care." British Medical Journal 323: 275-279.

British Academy. 2004. "That Full Complement of Riches": The Contributions of the Arts, Humanities, and Social Sciences to the Nation's Wealth. Langford Report. London: British Academy.

Cartwright, Nancy, and Jacob Stegenga. 2011. "A Theory for Evidence-Based Policy.” In Evidence, Inference and Enquiry, edited by Philip Dawid, William Twining, and Mimi Vasilaki, 291-322. Oxford: Oxford University Press.

Commission on Humanities and Social Sciences. 2013. The Heart of the Matter. Cambridge, MA: American Academy of Arts and Sciences. http://www.amacad.org.

Cook, Walter Wheeler. 1927. "Scientific Method and the Law." American Bar Association Journal 13: 303-309.

Dagan, Hanoch. 2013a. "Law as an Academic Discipline." Social Science Research Network. http://papers.ssrn.com/sol3/papers

Dagan, Hanoch. 2013b. Reconstructing American Legal Realism and Rethinking Private Law Theory. New York: Oxford University Press.

Davis, Kevin E., Benedict Kingsbury, and Sally Engle Merry. 2012. "Introduction: Governance by Indicators." In Governance by Indicators: Global Power through Quantification and Rankings, edited by Kevin Davis, Angelina Fisher, Benedict Kingsbury, and Sally Engle Merry, 3-28. Oxford: Oxford University Press.

de Been, Wouter. 2008. Legal Realism Regained: Saving Realism from Critical Acclaim. Stanford: Stanford University Press.

Del Mar, Maksymilian, and William Twining, eds. 2015. Legal Fictions in Theory and Practice. Heidelberg: Springer.

Dickson, Julie. 2012. "The Idea of a Legal System: Between the Real and the Ideal." In MacCormick's Scotland, edited by Neil Walker, 145-162. Edinburgh: Edinburgh University Press.

Dresch, Paul, and Hannah Skoda, eds. 2012. Legalism: Anthropology and History. Oxford: Oxford University Press.

du Marais, Bertrand, ed. 2006. Des indicateurs pour mesurer le droit? Les limites méthodologiques des rapports Doing Business (La documentation Française).

Dworkin, Ronald. 1977. Taking Rights Seriously. London: Duckworth.

Dworkin, Ronald. 1994. Life's Dominion. New York: Vintage. 
Dworkin, Ronald. 2006a. "Hart and the Concepts of Law." Harvard Law Review Forum: 95-104.

Dworkin, Ronald. 2006b. Justice in Robes. Cambridge: Harvard University Press.

Dworkin, Ronald. 2011. Justice for Hedgehogs. Cambridge: Harvard University Press.

Engelmann, Stephen G., ed. 2011. Jeremy Bentham: Selected Writings. New Haven: Yale University Press.

Floyd, Jonathan, and Marc Stears, eds. 2011. Political Theory Versus History? Cambridge: Cambridge University Press.

Frank, Jerome. 1930. Law and the Modern Mind. New York: Brentano's.

Frank, Jerome. (1949) 1973. Courts on Trial: Myth and Reality in American Justice. Princeton: Princeton University Press.

Galligan, Denis J. 2007. Law in Modern Society. Oxford: Oxford University Press.

Gardner, John. 2012. Law as a Leap of Faith. Oxford: Oxford University Press.

Garth, Bryant G. 2006. "Introduction: Taking New Legal Realism to Transnational Issues and Institutions." Law \& Social Inquiry 31(4): 939-945.

Genn, Hazel, Martin Partington, and Sally Wheeler. 2006. Law in the Real World: Improving Our Understanding of How Law Works. London: Nuffield Foundation (The Genn Report).

Geuss, Raymond. 2001. History and Illusion in Politics. Cambridge: Cambridge University Press.

Glenn, H. Patrick. 2007. Legal Traditions of the World: Sustainable Diversity in Law, $3^{\text {rd }}$ edition. Oxford: Oxford University Press.

Griffiths, John. 2003. "The Social Working of Legal Rules." Journal of Legal Pluralism and Unofficial Law 48: 1-84.

Haack, Susan. 1998. Manifesto of a Passionate Moderate. Chicago: University of Chicago Press.

Hall, Edward. 2013. "Political Realism and Fact-Sensitivity." Res Publica 19(2): 173-181.

Halpin, Andrew. 2004. Definition in Criminal Law. Oxford: Hart Publishing.

Halpin, Andrew. 2006. "The Methodology of Jurisprudence: Thirty Years off the Point." Canadian Journal of Law and Jurisprudence 19: 67-105.

Halpin, Andrew. 2009. "Methodology and the Articulation of Insight: Some Lessons from MacCormick's Institutions of Law." In Law as Institutional Normative Order, edited by Maksymilian Del Mar and Zenon Bankowski, 145-16o. Farnham: Ashgate.

Hart, Herbert L.A. (1961) 1994. The Concept of Law ( $2^{\text {nd }}$ edn. including Postscript). Oxford: Oxford University Press.

Hart, Herbert L.A. 1983. "American Jurisprudence Through English Eyes: The Nightmare and the Noble Dream." In Essays in Jurisprudence and Philosophy, by Herbert L.A. Hart, 123-144. Oxford: Oxford University Press.

Headland, Thomas, Kenneth Pike, and Marvin Harris, eds. 1990. Emics and Etics: The Insider/Outsider Debate. London: Sage.

Hurst, James Willard. 1964. Law and Economic Growth: The Legal History of the Lumber Industry in Wisconsin. Cambridge, MA: Harvard University Press.

Jolowicz, John Anthony, ed. 1970. The Division and Classification of the Law: Papers Submitted to the Joint Seminar of the Society of Public Teachers of Law and the Law Commissions of England and Scotland. London: Butterworths.

Kritsiotis, Dino, and Christopher McCrudden, eds. 2012. "Symposium: Brian Simpson's Reflections on "The Concept of Law." Transnational Legal Theory 3(2).

Lacey, Nicola. 2006. "Analytical Jurisprudence Versus Descriptive Sociology Revisited." Texas Law Review 88: 945-982. 
Lacey, Nicola. 2013. "Institutionalising Responsibility: Implications for Jurisprudence." Jurisprudence 4(1): 1-19.

Legal Education and Training Review. 2013. Setting Standards: The Future of Legal Services Education and Training Regulation in England and Wales. London. http://letr.org.uk/thereport.

Leiter, Brian. 2003. “What Is Legal Realism?” Leiter Reports: A Philosophy Blog, November 13, http://leiterreports.typepad.com/blog/2003/11/what_is_legal_r.html.

Leiter, Brian. 2007. Naturalizing Jurisprudence: Essays on American Legal Realism and Naturalism in Legal Philosophy. Oxford: Oxford University Press.

Lipton, Peter. 2001. "The History of Empiricism.” In International Encyclopedia of Social and Behavioral Sciences, edited by Neil J. Smelser and Paul B. Baltes, 4481-4485. Oxford: Elsevier.

Llewellyn, Karl N. (1930) 2008. The Bramble Bush: The Classic Lectures on the Law and Law School (With a New Introduction and Notes by Steve Sheppard). New York: Oxford University Press.

Llewellyn, Karl N. 1941. “The Theory of Legal Science.” North Carolina Law Review 20: 1-23.

Llewellyn, Karl N. 1942-1943. "Babel versus Teamwork", unpublished manuscript. Karl Llewellyn Papers, University of Chicago (KLP. B., III, 37d).

Llewellyn, Karl N. 1952. "The Adventures of Rollo: Opening Talk in Elements Class." University of Chicago- The Law School Record 2(1): 23.

Llewellyn, Karl N. 1958. "Law in our Society": teaching materials, unpublished. Karl Llewellyn Papers, University of Chicago.

Llewellyn, Karl N. 1960. The Common Law Tradition: Deciding Appeals. Boston: Little, Brown.

Llewellyn, Karl N. 2011. The Theory of Rules. Edited by Frederick Schauer. Chicago: University of Chicago Press.

Llewellyn, Karl N., and E. Adamson Hoebel. 1941. The Cheyenne Way. Norman: University of Oklahoma Press.

Macaulay, Stewart. 2005. “The New Versus the Old Legal Realism: ‘Things Ain't What They Used To Be." Wisconsin Law Review 2005(2): 365-403.

Macaulay, Stewart, and Elizabeth Mertz. 2013. "New Legal Realism and the Empirical Turn in Law." In Law and Social Theory, $2^{\text {nd }}$ edition, edited by Reza Banakar and Max Travers, 195-210. Oxford and Portland: Hart Publishing.

MacCormick, Neil. 2007. Institutions of Law: An Essay in Legal Theory. Oxford: Oxford University Press.

Merry, Sally Engle. 2006. "New Legal Realism and the Ethnography of Transnational Law." Law \& Social Inquiry 31(4): 975-995.

Merryman, John. 1954. "The Authority of Authority: What the California Supreme Court Cited in 1950." Stanford Law Review 6: 613-673.

Mertz, Elizabeth. 2016. "New Legal Realism: Law and Social Science in the New Millennium." In The New Legal Realism: Translating Law-and-Society for Today's Legal Practice, edited by Elizabeth Mertz, Stewart Macaulay, and Thomas W. Mitchell, 1-25. New York: Cambridge University Press.

Moore, Underhill, and Charles C. Callahan. 1943. "Law and Learning Theory: A Study in Legal Control.” Yale Law Journal 53: 1-136.

Nelken, David. 1981. "The 'Gap Problem' in the Sociology of Law: A Theoretical Overview." Windsor Yearbook of Access to Justice 1: 35-61.

"New Legal Realism Conversations: An Empirical Law and Society Blog." Accessed January 31, 2014. http://newlegalrealism.wordpress.com/. 
Nussbaum, Martha. 2010. Not For Profit: Why Democracy Needs the Humanities. Princeton: Princeton University Press.

Osborne, Henry, ed. 1970. The Oxford Companion to Art. Oxford: Clarendon Press.

Powe, Lucas A. 2001. The Warren Court and American Politics. Cambridge, MA: Harvard University Press.

Power, Michael. 1997. The Audit Society: Rituals of Verification. Oxford: Clarendon Press.

Quinn, Michael. 2015. "Fuller on Legal Fictions: A Benthamic Perspective." In Legal Fictions in Theory and Practice, edited by Maksymilian Del Mar and William Twining, 55-82. Heidelburg: Springer.

Raz, Joseph. 1990. Practical Reason and Norms. Princeton: Princeton University Press.

Raz, Joseph. 1992. The Concept of a Legal System, $2^{\text {nd }}$ edition. Oxford: Oxford University Press.

Raz, Joseph. 2005. “Can There Be a Theory of Law?” In Blackwell Guide to Philosophy of Law and Legal Theory, edited by Martin P. Golding and William A. Edmundson, 324-342. Malden, MA: Blackwell Publishing.

Raz, Joseph. 2009. The Authority of Law, $2^{\text {nd }}$ edition. Oxford: Oxford University Press.

Restrepo-Ameriles, David. 2014. "The Mathematical Turn: L'indicateur Rule of Law dans la politique de developpment de la Banque Mondial.” In Gouverner Par Les Normes Et Les Indicateurs, edited by Benoit Frydman and Arnaud Van Waeyenberge, 193-234. Brussells: Bruylant.

Roberts, Paul, and Adrian Zuckerman. 2010. Criminal Evidence, $2^{\text {nd }}$ edition. Oxford: Oxford University Press.

Rorty, Richard. 1991. Objectivity, Relativism and Truth. Cambridge: Cambridge University Press.

Russell, Jill, and Trisha Greenhalgh. 2011. "Rhetoric, Evidence and Policy-Making: A Case Study of Priority Setting in Primary Care." In Evidence, Inference and Enquiry, edited by Philip Dawid, William Twining, and Mimi Vasilaki, 267-290. Oxford: Oxford University Press.

Salmond, Sir John. (1953) 1973. The Law of Torts, $11^{\text {th }}$ edition $\left(16^{\text {th }}\right.$ edn.). Edited by R.F.V. Heuston. London: Sweet and Maxwell.

Schauer, Frederick. 1991. Playing by the Rules. Oxford: Oxford University Press.

Schauer, Frederick. 2009. "Institutions and the Concept of Law: A Reply to Ronald Dworkin (with some help from Neil MacCormick).” In Law as Institutional Normative Order, edited by Maksymilian Del Mar and Zenon Bankowski, 35-44. Farnham: Ashgate.

Schauer, Frederick., ed. 2011. Karl Llewellyn: The Theory of Rules. Chicago: University of Chicago Press.

Schauer, Frederick. 2012. "Foreword". In Karl Llewellyn and the Realist Movement, William Twining, ix-xxiv. New York: Cambridge University Press.

Schlegel, John H. 1995. American Legal Realism and Empirical Social Science. Chapel Hill: University of North Carolina Press.

Schofield, Philip. 2006. Utility and Democracy: The Political Thought of Jeremy Bentham. Oxford: Oxford University Press.

Sen, Amartya. 2004. "Elements of a Theory of Human Rights." Philosophy and Public Affairs 32: $315-356$.

Sen, Amartya. 2009. The Idea of Justice. Cambridge, MA: Harvard University Press.

Shapiro, Scott. 2011. Legality. Cambridge, MA: Harvard University Press.

Simpson, A. W. Brian. 1984. Cannibalism and the Common Law. Chicago: University of Chicago Press.

Simpson, A. W. Brian. 1995. Leading Cases in the Common Law. Oxford: Clarendon Press. 
Simpson, A. W. Brian. 2011. Reflections on "The Concept of Law." Oxford: Oxford University Press.

Solesbury, William. 2001. "Evidence Based Policy: Whence It Came and Where It's Going." ESRC UK Centre for Evidence Based Policy and Practice Working Paper \#1, available at http://www.kcl.ac.uk/sspp/departments/politicaleconomy/research/cep/pubs/papers/papero1.aspx. Accessed Feb. 18, 2015.

Starr, June, and Jane F. Collier, eds. 1989. History and Power in the Study of Law. Ithaca, NY: Cornell University Press.

Stone, Julius. 1956. The Province and Function of Law. Cambridge, MA: Harvard University Press.

Suchman, Mark, and Elizabeth Mertz. 2010. "Toward a New Legal Empiricism: Empirical Legal Studies and New Legal Realism”. Annual Review of Law and Social Science 6(1): $555-576$.

Tamanaha, Brian Z. 1997. Realistic Socio-Legal Theory: Pragmatism and a Social Theory of Law. Oxford: Oxford University Press.

Tamanaha, Brian Z. 2001. A General Jurisprudence of Law and Society. Oxford: Oxford University Press.

Tamanaha, Brian Z. 2013. “The Third Pillar of Jurisprudence: Social Legal Theory." Social Science Research Network. http://papers.ssrn.com/sol 3/papers.cfm?abstract_id=2256622.

Twining, William. 2000. Globalisation and Legal Theory. London: Butterworth and Evanston: Northwestern University Press.

Twining, William. 2002. The Great Juristic Bazaar: Jurists' Texts and Lawyers' Stories. Aldershot: Ashgate.

Twining, William. 2005. "Have Concepts, Will Travel." International Journal of Law in Context 1: 5-40.

Twining, William. 2006. Rethinking Evidence: Exploratory Essays, $2^{\text {nd }}$ edition. Cambridge: Cambridge University Press.

Twining, William. 2009. General Jurisprudence: Understanding Law from a Global Perspective. Cambridge: Cambridge University Press.

Twining, William. 2011a. "Normative and Legal Pluralism." Duke Journal of Comparative and International Law Journal 20: 473-517.

Twining, William. 2011b. Globalisation and Legal Scholarship (Montesquieu Lectures). Nijmegen: Wolf.

Twining, William. (1973/1985) 2012a. Karl Llewellyn and The Realist Movement, $2^{\text {nd }}$ edition (with afterword). New York: Cambridge University Press.

Twining, William. (1973/1985) 2012b. "Afterword." In Karl Llewellyn and the Realist Movement, $2^{\text {nd }}$ edition (with afterword), edited by William Twining, 388-443. New York: Cambridge University Press.

Twining, William. 2012c. "What Is the Point of Legal Archeology?" Transnational Legal Theory 3(2): 166-172.

Twining, William, and David Miers. (1973) 2010. How to Do Things with Rules, $5^{\text {th }}$ edition. Cambridge: Cambridge University Press.

Walker, Neil, ed. 2012. MacCormick's Scotland. Edinburgh: Edinburgh University Press.

Williams, Bernard. 1985. Ethics and the Limits of Philosophy. London: Fontana. 